\title{
DỨBin
}

Technological University Dublin ARROW@TU Dublin

\section{Reiterating Asylum Archive: documenting direct provision in Ireland}

Vukasin Nedeljkovic

Technological University Dublin, asylumarchive@gmail.com

Follow this and additional works at: https://arrow.tudublin.ie/gradcamart

Part of the Photography Commons

\section{Recommended Citation}

Vukasin Nedeljkovic (2018) Reiterating Asylum Archive: documenting direct provision in Ireland, Research in Drama Education: The Journal of Applied Theatre and Performance, 23:2, 289-293, DOI: 10.1080/ 13569783.2018.1440202

This Article is brought to you for free and open access by the Graduate School of Creative Arts and Media at ARROW@TU Dublin. It has been accepted for inclusion in Articles by an authorized administrator of ARROW@TU Dublin. For more information, please contact arrow.admin@tudublin.ie, aisling.coyne@tudublin.ie, gerard.connolly@tudublin.ie.

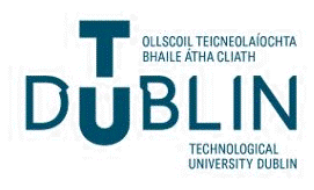




\section{Research in Drama Education: The Journal of Applied Theatre and Performance}

\section{Reiterating Asylum Archive: documenting direct provision in Ireland}

\section{Vukasin Nedeljkovic}

To cite this article: Vukasin Nedeljkovic (2018) Reiterating Asylum Archive: documenting direct provision in Ireland, Research in Drama Education: The Journal of Applied Theatre and Performance, 23:2, 289-293, DOI: 10.1080/13569783.2018.1440202

To link to this article: https://doi.org/10.1080/13569783.2018.1440202

\section{Published online: 10 Apr 2018.}

\section{Submit your article to this journal $₫$}

III Article views: 1229

Q View related articles $\asymp$

View Crossmark data $₫$ 


\title{
Reiterating Asylum Archive: documenting direct provision in Ireland
}

\author{
Vukasin Nedeljkovic \\ Dublin Institute of Technology, Dublin, Ireland
}

\begin{abstract}
Originally a coping mechanism for an artist housed in a Direct Provision Centres while seeking asylum in Ireland, Asylum Archive has become much more than that. In 2018, it is now a collaborative archive, interactive and intermedial online document, and a scholarly research project. This iteration includes five new images of Railway Direct Provision Centre in Kiltimagh.
\end{abstract}

\section{KEYWORDS}

Archive; detention; deportation; direct provision; Ireland

From April 2007 to November 2009, I was housed in a Direct Provision Centre (DP) while seeking asylum in Ireland. Introduced in November 1999, the Direct Provision system provides asylum seekers with accommodation, access to medical care and a small living allowance; it also provides children with access to mainstream schooling. Well, that is the official version. The reality is that, as I have written elsewhere, the more than 150 centres are located outside cities - in former convents, army barracks, and hotels - on the periphery of society (see Nedeljkovic 2015; 2016). Residents live in dirty, cramped conditions, with families often forced to share small rooms. Managers control every aspect of their lives: meals, mobility, access to bed linen and cleaning supplies. ${ }^{1}$

Critics like sociologist Ronit Lentin have described DP as 'holding camps' and sites of 'deportability' which 'construct their inmates as deportable subjects, ready to be deported at any time' (2012). Likewise, Dublin's Free Legal Advice Centre has stated that these privately owned centres 'operat[e] as an industry rather than a means by which the government is fulfilling its human rights commitments' $(2009,11)$. In historical terms, the scheme continues Ireland's shameful tradition of confinement, whether through borstals, laundries, prison, mother and baby homes, and lunatic asylums. In theoretical terms, these centres resemble what sociologist Erving Goffman termed a 'total institution', which are defined by three main characteristics. First, 'all aspects of life are conducted in the same place and under the same authority' ([1961] 2007, 6). In addition, each 'daily activity is carried on in the immediate company of others, all of whom are treated alike and ... do the same thing together' (6). Lastly, 'the day's activities are tightly scheduled [and] imposed from above' (6). Total institutions are, according to Goffman, 'forcing houses for changing persons; each is a natural experiment on what can be done to the self' (12). Though it was first published over 50 years ago, in 1961, it would be hard to find a more accurate account of these centres (Figures 1-5). 


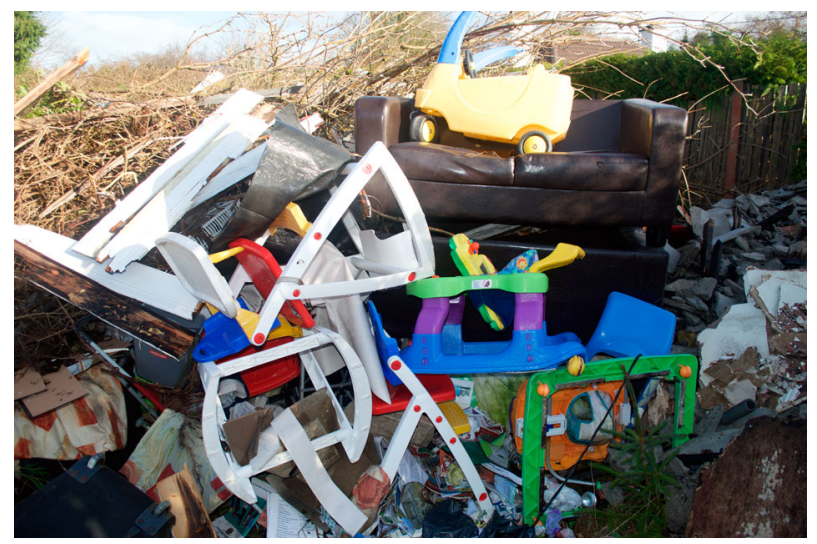

Figure 1. Railway Direct Provision Centre, Kiltimagh, County Mayo, Ireland.

Other ways of framing direct provision might draw on sociologist Marc Augé's term 'non-place'; centres are 'non-places' for those who, according to the government, are 'non-people' (Augé 1995). Or we might look to philosopher Emmanuel Levinas and say that DPs are 'the absence of everything ... the place where the bottom has dropped out of everything, an atmospheric density, a plenitude of the void, or the murmur of silence' (Lévinas 1987, 46). Or we might turn to art, as I have in Asylum Archive. What started as a coping mechanism has now become the primary focus of my research, as part of my PhD at the Dublin Institute of Technology. It was, and is, directly concerned with the realities and traumatic lives of asylum seekers. It aims to collaborate with asylum seekers, artists, academics and activists to create an interactive and intermedial documentary that records accounts of exile, displacement, trauma and memory. For the most part, this documentary exists as a website (www.asylumarchive.com).

However, it has also been exhibited at the Galway Arts Centre in Galway in 2015 and the NCAD (National College of Art and Design) Gallery in Dublin in 2017 and published in TransActions, an online publication dedicated to transdisciplinary artistic practices, in an issue about socially engaged art (Nedeljkovic 2015). The following year it

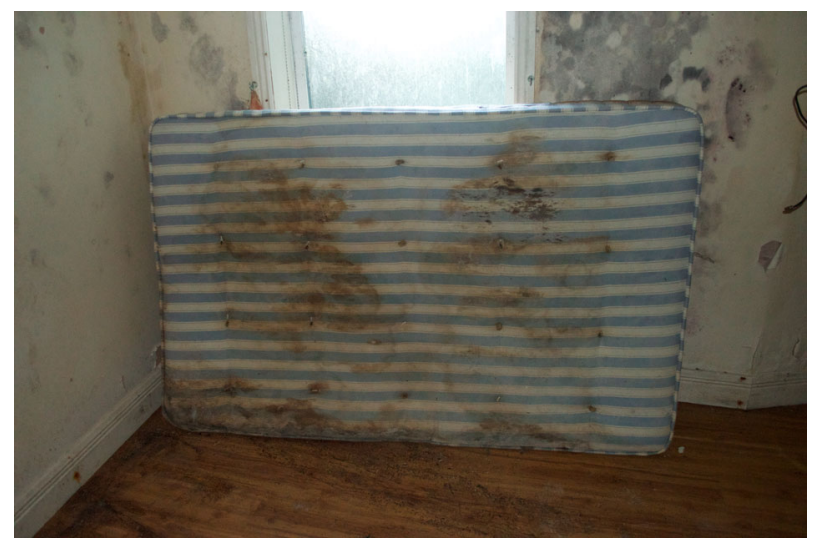

Figure 2. Railway Direct Provision Centre, Kiltimagh, County Mayo, Ireland. 


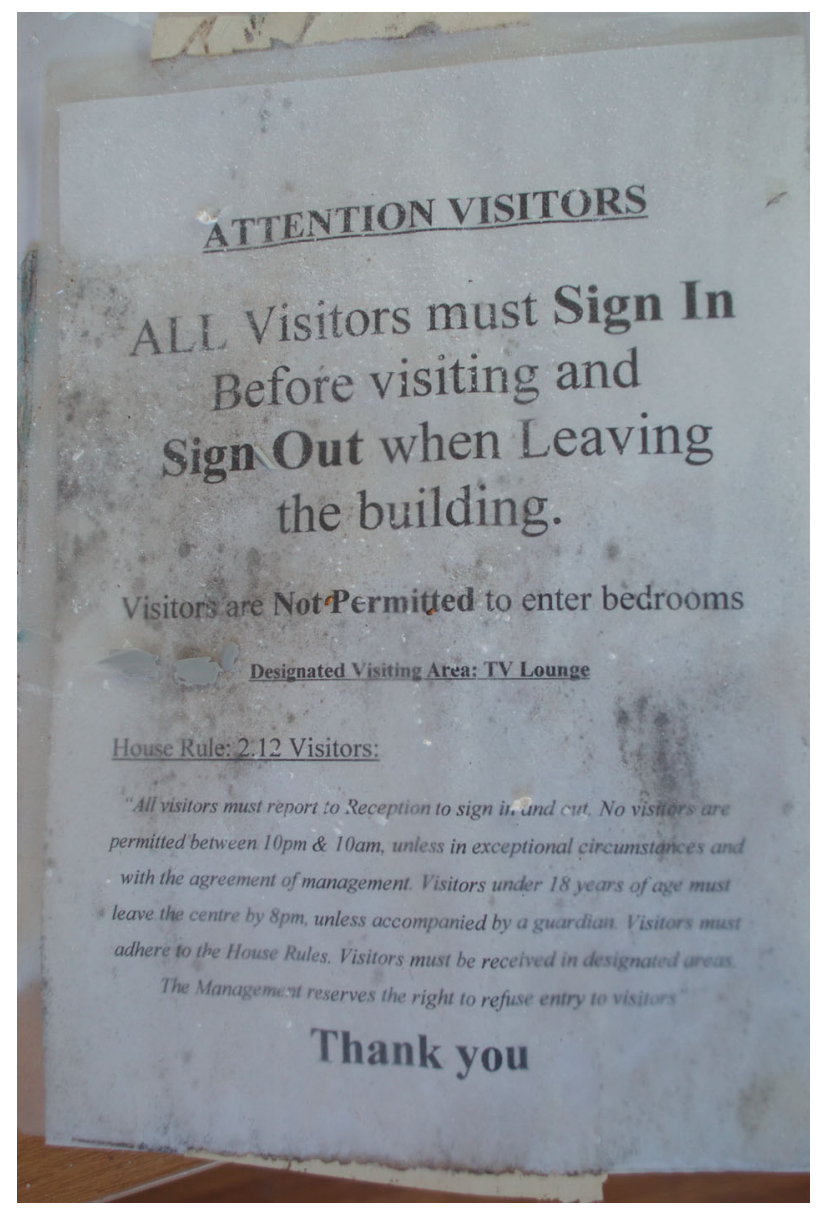

Figure 3. Railway Direct Provision Centre, Kiltimagh, County Mayo, Ireland.

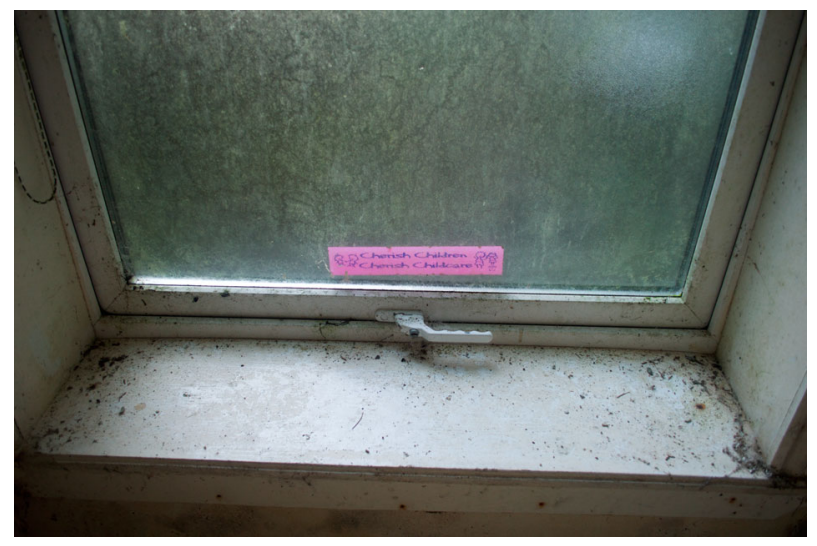

Figure 4. Railway Direct Provision Centre, Kiltimagh, County Mayo, Ireland. 


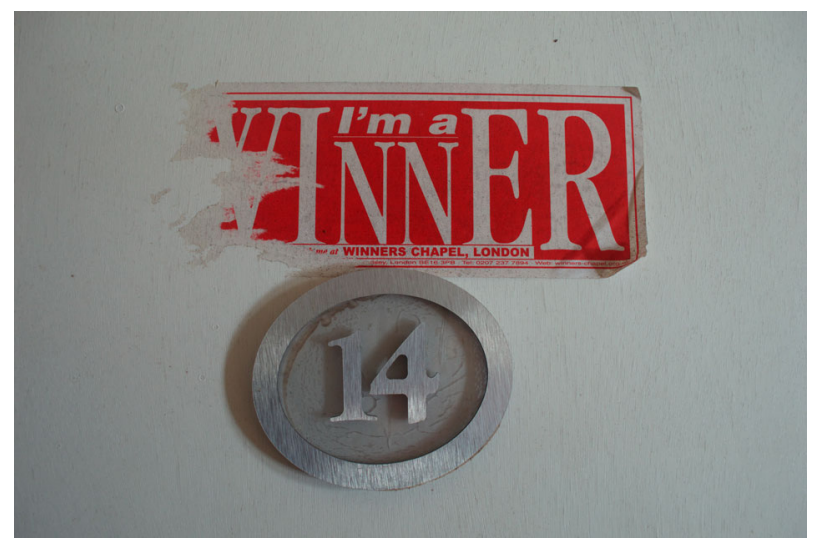

Figure 5. Railway Direct Provision Centre, Kiltimagh, County Mayo, Ireland.

was published on the University of Oxford Faculty of Law's Border Criminologies blog (Nedeljkovic 2016). In each reiteration, Asylum Archive takes on a slightly different quality. In the exhibition at Galway, photographs could appear alongside videos and found objects. In addition, the gallery hosted a discussion panel, which was in turn recorded and made available online (http://www.create-ireland.ie/audio/onsoundcloud-asylum-archive). The same happened at the NCAD Gallery and in both instances, the white cube emphasised the archive's artistic qualities. By contrast, my account in TransActions emphasises the project's resistant qualities, arguing that asylum seekers resist the DP centres, which have been designed as sites of detention and exclusion, by reclaiming them as sites of collectivity and solidarity. Similarly, Asylum Archive resists the artistic convention of 'humanising' asylum seekers through storytelling by refusing to include any humans at all in the images. Lastly, the Border Criminologies version includes by far the most images, almost as if the art has to become evidence in a legal context.

Taken together, these reiterations of Asylum Archive document, analyse and theorise experiences of power, authority, detention and supervision. Asylum Archive serves as a repository of asylum experiences and artefacts and it has an essential visual and educational perspective, accessible through its online presence to any future researchers and scholars who may wish to study the conditions of asylum seekers in Ireland.

In this iteration for Research in Drama Education, I have included five new images of former Railway Direct Provision Centre in Kiltimagh in County Mayo. Railway Direct Provision Centre opened at the end of 2003 and subsequently closed in the summer of 2009. It was located in Kiltimagh, a small rural town in the West of Ireland. The capacity of the Centre was approximately 90 people; women, men and children. The residents of the Centre have integrated in to the local community, they attended different activities and classes. After the closure the residents of Railway Direct Provision Centre were dispersed across other different Centres in the Republic of Ireland. I gained access to the Centre in 2018 and was able to photographs what one community has left behind; their belongings, traces, signs, memories and remnants. 


\section{Note}

1. Versions of the following two paragraphs have appeared previously (Nedeljkovic 2016, 2016). However, the images of the Railway Direct Provision Centre have not been previously published nor has my commentary on them.

\section{Disclosure statement}

No potential conflict of interest was reported by the author.

\section{Notes on contributor}

Vukasin Nedeljkovic is an independent artist, researcher and curator. Among his recent multidisciplinary projects is Asylum Archive, which was initiated through his own experience of the Direct Provision system and has since extended to include digital, material and visual materials from asylum seekers in Ireland.

\section{References}

Augé, Marc. 1995. Non-places: Introduction to an Anthropology of Supermodernity. Translated by John Howe. London: Verso.

FLAC (Free Legal Advice Centre). 2009. One Size Doesn't Fit All: A Legal Analysis of the Direct Provision and Dispersal System in Ireland, 10 Years On. Dublin: Free Legal Advice Centre. http://www.flac.ie/ download/pdf/one_size_doesnt_fit_all_full_report_final.pdf.

Goffman, Erving. (1961) 2007. Asylums: Essays on the Social Situation of Mental Patients and Other Inmates. 2nd ed. with a new introduction by William B. Helmreich. New Brunswick: Transaction Publishers.

Lentin, Ronit. 2012. "Anti-Deportation Ireland: End Deportations." Ronit Lentin, October 4. http:// www.ronitlentin.net/2012/10/04/anti-deportation-ireland-end-deportations-now/.

Lévinas, Emmanuel. 1987. Time and the Other, and Additional Essays. Translated by Richard A. Cohen. Pittsburgh, PA: Duquesne University Press.

Nedeljkovic, Vukasin. 2015. "Direct Provision Centres as Manifestations of Resistance." Transactions: Dialogues in Trans-Disciplinary Practice, June 9. http://issue1.transactionspublication.com/2015/06/ 09/direct-provision-centers-as-manifestations-of-resistance/.

Nedeljkovic, Vukasin. 2016. "Asylum Archive: An Archive of Direct Provision in Ireland." Border Criminologies, May 4. https://www.law.ox.ac.uk/research-subject-groups/centre-criminology/ centreborder-criminologies/blog/2016/05/asylum-archive. 